\title{
S:Pububsaúde
}

ARTIGO ORIGINAL

\section{Dissemination of knowledge and scientific production in professionalizing courses: a report of experience}

\section{Disseminação do conhecimento e produção científica em cursos profissionalizantes: um relato de experiência}

\section{Silvio de Almeida Junior1, 30 , Mateus Matos da Silva ${ }^{2}$, Rafaela Simei Popolim ${ }^{0}$, Cristian Ribeiro Gonçalves ${ }^{\bullet}$, Matheus Reis Santos de Melo ${ }^{\circ}$, Danilo Cândido Bulgo 40}

'Universidade de Franca, Programa de Pós-Graduação em Ciência Animal, Laboratório de Ciência Animal, Franca, São Paulo, Brasil. ¿ Universidade Federal de Alfenas, Alfenas, Minas Gerais, Brasil. 3 Euro Anglo Cursos Profissionalizantes, Grupo de Pesquisa em Toxicologia e Promoção da Saúde, Franca, São Paulo, Brasil. 4Universidade de Franca, Programa de Pós-graduação em Promoção de Saúde, Franca, São Paulo, Brasil. 5Universidade de Franca, Laboratório de Mutagênese, Franca, São Paulo, Brasil.

\section{E-mail: silvioalmeidajr@yahoo.com.br}

Como citar: Almeida Junior, S., Silva, M.S. Popolim, R.S., Goncalves, C.R., Melo, M.R.S., Bulgo, D.C. 2019. Dissemination of knowledge and scientific production in professionalizing courses: a report of experience, $2, \quad$ a008. DOl: https://dx.doi.org/10.31533/pubsaude2.a 008

Recebido: 05 ago. 2019

Revisado e aceito: 31 ago. 2019.

Conflito de interesse: OS autores declaram, em relação aos produtos e companhias descritos nesse artigo, não ter interesses associativos, comerciais, de propriedade ou financeiros que representem conflito de interesse.

Licenciamento: Este artigo é publicado na modalidade Acesso Aberto sob a licença Creative Commons Atribuição 4.0 (CC-BY 4.0).
A b stract. With the construction of the individual and the phase of choices characterized by adolescence, young people are looking for more and more free courses in order to become professional and have a career orientation to follow. Therefore, the work aims to evaluate the scientific construction versus the production of work in professional courses. The work was developed with 15 classes of Pharmacy Assistant and Laboratory, 3 classes of Veterinary Assistant and Pet Shop and 2 classes of Elderly Caregiver. In all, 33 papers were presented between local, regional, national and international congresses. In front of what has been reported, it is possible to affirm that when well structured a Junior Scientific Initiation program has effectiveness in the social, professional and scientific formation of young people assisted and the interaction among students. From interdisciplinarity, the construction of scientific thinking corroborates the formation of a being inserted in society, with collective dimensions of knowledge built by man.

Keywords: vocational courses, didactics, active teaching methodologies.

R e s u m o . Com a construção do indivíduo e a fase de escolhas caracterizadas pela adolescência, os jovens buscam cada vez mais cursos livres para se profissionalizar e seguir uma orientação profissional. Portanto, o trabalho visa avaliar a construção científica versus a produção de trabalho em cursos 
profissionalizantes. O trabalho foi desenvolvido com 15 classes de Assistente de Farmácia e Laboratório, 3 aulas de Assistente Veterinário e Pet Shop e 2 aulas de Cuidador de Idosos. Ao todo, 33 artigos foram apresentados entre congressos locais, regionais, nacionais e internacionais. Frente ao que foi relatado, é possível afirmar que, quando bem estruturado, um programa de Iniciação Científica Júnior tem efetividade na formação social, profissional e científica de jovens assistidos e na interação entre os alunos. Da interdisciplinaridade, a construção do pensamento científico corrobora a formação de um ser inserido na sociedade, com dimensões coletivas de conhecimento construídas pelo homem.

P a l avra s-ch ave : cursos profissionalizantes, didática, metodologias ativas de ensino.

\section{INTRODUCTION}

The search for professionalization in the current market is increasing due to broad competition. The profile of the student in which he seeks a professionalization is given as low income and seeks to help him to quickly enter the labor market. The search for these courses is given by being fast, inexpensive when compared to technical or higher education (Severnini \& Orellano, 2010). In communion with this group, adolescents between the ages of 14 and 18, search for these free courses, with professionalization as a basis for decision making. Adolescence is characterized as a phase of many choices and free courses are offered in the intention of targeting these young people. Adherence to these courses concomitant with high school is of great value and brings professional and personal benefits to the assistants, in another words, young people of the low income setting (Nascimento, 2007).

In relation to what is found in the literature, relating to data developed in a vocational school, the objective of this work is to evaluate the teaching and scientific production in a vocational school, as well as its social impact. Such work is justified due to the absence of content produced for vocational courses, being described in the research bases, information related to technical, higher and post-graduate courses.

In adolescence the individual lives a phase of constant changes, not only as regards the physiological part (hormonal, cognitive and psychological), but also the expectation of changes. From this moment, the construction of the adult being is initiated, with the decision making (Sparta \& Gomes, 2005).

Often, it is the teacher's difficulty in transposing the content to the student, leading to a loss of stimulation, especially within the area of science applied to health. The pedagogical accompaniment related to educational practices is necessary since courses within the health area 
need these specific and technical training, guaranteeing the health and quality of care provided (Gazzinelli et al., 2005). The increase of the knowledge in the classroom to a scientific knowledge, raises the degree of interest of the students on science teaching, bringing greater effectiveness of pedagogical practices directed to a specific public, of greater interest (Gadotti, 2000).

The change that the teacher is the maximum authority and holder of all knowledge and that it always has correct answers falls to the ground when the individual begins to question. This makes the teacher to develop continuously, to further improve his student (Fava-de-Moraes \& Fava, 2000; Ventura et al., 2011).

It is possible to observe that health education obtains greater results when worked with active pedagogical methodologies, bringing the student closer to the teacher and discussing cases of lived reality. This shows greater interaction and greater social development, since the subject is diffused in front of the population in which the youth is inserted (Uchoa et al., 2000).

\section{METHODOLOGICAL PROCEDURES}

\section{CHARACTERIZATION OF THE ENVIRONMENT}

The work was developed in a vocational school unit in a medium sized city. The school has been established in the city for seven years and generates professional knowledge in the areas of technology (basic computer science, advanced, hardware), language (English), management (business and legal) and health (pharmacy and laboratory, veterinary and caregiver of the elderly). The courses are of free format, lasting from six months to two years. The project was developed between June 2017 and September 2018. The project was developed with the inclusion of 15 classes of the Pharmacy and Laboratory Vocational Course, 3 classes of Veterinary Assistant and Pet Shop and 2 classes of Elderly Caregiver.

\section{EXPERIMENTAL DESIGN}

Initially, for the implementation of this project, the courses of the health area were selected (Pharmacy Assistant and Laboratory, Veterinary Assistant and Pet Shop and Elderly Caregiver). Then, a pedagogical evaluation was carried out on the programmatic content of the courses in the area of health and possible inclusions of scientific practices that came within its scope. The intention of practical activities 
involves the student in a constant way and improves their cognitive development, leading to a more effective teaching-learning practice.

The second phase of the work was carried out in the preparation of scientific work with the students of the three courses mentioned above and the beginning of scientific production. In the final activity, the dissemination of research data through presentations at meetings, symposia and congresses was carried out.

\section{RESULTS AND DISCUSSION}

From the construction of scientific thinking and technical-scientific development in the classroom, the students left to present scientific events and congresses within the area of science and health promotion, being the applications of the work in human and animal health. The development of projects by the students themselves and guided by the teachers, added values and dimensions to the participants. Between 2017 and 2018, 33 works were presented at local, regional, national and international congresses, in the form of poster, $\mathrm{v}$-poster and oral presentations.

The works presented represent 59\% to the students of the Pharmacy and Laboratory Course; $22 \%$ to the Veterinary Assistant and Pet-Shop course and $19 \%$ to the Elderly Caregiver course. The high number of jobs for Pharmacy Assistant and Laboratory students is justified because the course exists the longest and is well consolidated in the unit, with a high number of students. In the course of the work, it is possible to observe that the first event was held among the unit's professors as an experiment pilot in 2017. The project resulted in the production of a paper presented at the 51st Brazilian Congress of Clinical Pathology and Laboratory Medicine, in the city of São Paulo / SP. From this project, students realized that content developed within the classroom could be taken to a big-name event.

In the same year, inspired by the previous event, the students participated in the II Human Anatomy Meeting of the Triângulo Mineiro, in the city of Uberaba / MG. In the event, eight papers were presented in the area of anatomy, pathological anatomy, teaching of morphological sciences and comparative anatomy. A highlight of the event was the highlight of a student participant from the school, who was appreciated with the "Highlight Student" award, and congratulated by the scientific director of the Brazilian Society of Anatomy, present at the venue. Among the participants in the scientific communications, there was a great astonishment due to the great number of works presented, besides the quality of scientific content and preparation observed during the presentation of the panels, because it was a vocational school. The evaluation of the evaluators was so great that the invitation to present 
work with final data was made at a future international congress. In the subsequent months, in another successful participation, two papers were presented during the II Meeting of Health Education of the Barretos Cancer Hospital, in Barretos/SP, working with teaching and correlation of natural products with possible anxiolytic activities. All works have always been based on popular medicine and evaluated together with national and international literature.

In 2018, continuing the scientific activities, the school participated in a virtual way, the 3rd Annual International Remote Conference: Science \& Society, which took place in the city of Toronto / Canada, with the exhibition of three works. The transposition of national barriers gave a great boost to students who realized they could go further. In the face of this, there was also the stimulation of learning a second language being important for scientific development within areas of science. With the increase in the demand of students with the intention to carry out scientific activities, it was evaluated that the number of research professors present in the unit was insufficient to attend to the interested parties. Faced with this, partnerships were held with undergraduate and graduate students from the city's universities. In February, from this partnership, a paper was presented in a closed event promoted by the University of São Paulo (USP), Ribeirão Preto campus, during the XVIII Summer Course: Genome, Proteome and the Cellular Universe: Oncology, Stem Cells and Cell Therapy.

In that same year, the Caregiver of the Elderly course presented his first work in the area of social and legal science, during the IX Research Show: from Scientific Initiation to Post-Graduation - UNESP Franca. The event took place at the Paulista State University (UNESP) and was promoted by PET - Social Service.

Two important events, with a major milestone in the project were the participation of the 52nd Brazilian Congress of Clinical Pathology and Laboratory Medicine in the city of Florianópolis/SC, with the presentation of eight papers; and the approval of presentation at the Latin American Regional Conference on Health Promotion and Health Education also with eight papers. The active participation of students, teachers and collaborating researchers led to an increase in scientific production and greater visibility for the school. Before the project was finalized, a health management work developed by a student during the non-compulsory stage to be presented during the Healthcare Advancement Conference - 2nd Latin American Forum ISQua was approved for presentation in the city of Cali / Colombia, a notoried-from event within the area of health and quality management with a focus on the patient.

In the intention of scientific production within a program of Scientific Initiation Junior de-developed together the classes of the professional 
courses transports barriers and causes the student to think in a scientific way. The transposition of the knowledge from the classroom to the research laboratory, causes the student to leave his habitual routine and dedicate himself to the new one, and seeing results, the same seeks to improve itself more and more (Fava-de-Moraes \& Fava, 2000).

As a professional formation, the student has different abilities from other students in which, they do not perform the same work. Habit of reading, synthesis of texts, critical judgment of situations based on preexisting or already known data. Communication in public, principles of autonomy, pro-activity, can be listed (Ferreira, 2003; Ribeiro, 2017). The experience within Junior scientific initiation has already been reported in other times applied to secondary education, as a source of benefit to students, and the preparation by scientific content based on questions of the students themselves brings advantages in their training, improvement of the process of understanding, and the custom of using scientific language, important facts for an entry in higher courses (Queiroz \& Almeida, 2004).

Participation in scientific events is very important when it is intended to disseminate knowledge, share experiences and expand the list of contacts in a given area. The report of scientific production and dissemination of the knowledge acquired are important to improve the life of the population. Conducting research without due social application is only an expenditure of resources (Schwartzman, 2002). Following the market and concerned with the development of students, at the end of the work and presentation of the results, the vocational school chose to open a space called "Nucleus of Scientific Initiation Junior" and acquisition of equipment to increase the number of practical research.

\section{FINAL CONSIDERATIONS}

In front of what has been reported, and knowing the range of information attributed to the work presented during events, it is possible to state that when well structured a Junior Scientific Initiation program has effectiveness in the social, professional and scientific formation of young people assisted. Also, it is possible to observe that students of vocational courses have a great potential of scientific development, provided that stimulated and oriented. The interaction between students, the work of interdisciplinary, the construction of scientific thinking help in the formation of a thinking being inserted in the society, with collective dimensions of the knowledge built by the man. 
This study was financed in part by the Coordenação de Aperfeiçoamento de Pessoal de Nível Superior - Brasil (CAPES) Finance Code 001".

\section{REFERENCES}

Fava-de-Moraes, F. \& Fava, M. 2000. Scientific initiation: many advantages and few risks. São Paulo On Perspect, 14(1), 73-77.

Ferreira, DT. 2003. Information professionals: skills profile demanded by the labor market. Ciência da Informação, 32(1), 42-49.

Gadotti, M. 2000. Current perspectives of education. São Paulo On Perspect, 14(2), 03-11.

Gazzinelli, MF., Gazzinelli, A., Reis, DC., Penna, CM. 2005. Health education: knowledge, social representations and experiences of the disease. Cadernos de Saúde Pública, 21(1), 200-206.

Nascimento, MNM. 2007. Middle school in brazil: historical determinations. UEPG Social Sciences, 15(1), 77-87.

Queiroz, SL. \& Almeida, MJPM. 2004. From making to understand science: reflections on students learning through undergraduate research projects in chemistry. Ciência \& Educação, 10(1), 41-53.

Ribeiro, ADL. 2017. Management of people (2a ed.). São Paulo, SP: Saraiva.

Schwartzman, S. 2002. Scientific Research and Public Interest. Revista Brasileira de Inovação, 1(2), 361-395.

Severnini, ER. \& Orellano, VIF. 2010. The Effect of the Professional Education on Probability of Insertion in the Labor Market and on Income in the Pre-PLANFOR Period. Economia, 11(1).

Sparta, M. \& Gomes, WB. 2005. Importance attributed to the entry into higher education by high school students. Revista Brasileira de Orientação Profissional, 6(2), 45-53.

Uchoa, E., Barreto, SM., Firmo, JO., Guerra, HL., Pimenta, FGJ., Lima e Costa, MF. 2000. The control of schistosomiasis in Brazil: an ethno-epidemiological study of the effectiveness of a community mobilization program for health education. Social Science \& Medicine, 51(10), 1529-1541.

Ventura, MCAA., Conceição e Neves, MMAM., Loureiro, CREC., Frederico-Ferreira, MM., Cardoso, EMP. 2011. The "good teacher": students opinion. Revista de Enfermagem referência, 3(5), 95-102.

\section{MINICURRÍCULO}

SILVIO DE ALMEIDA JUNIOR Master's degree in the Graduate Program in Animal Science, University of Franca. Docent / Researcher by Euro Anglo Vocational Courses, working in the division of professional courses in the areas of Health and Welfare. Biomedical graduate in Clinical Pathology and Microbiology. Specialization in Ludicism, Clinical and Institutional Psychopedagogy by the Faculty Dom Bosco. Advice on personal development 
and quality in clinical laboratory. *The present study was carried out with the support of the Coordination of Improvement of Higher Education Personnel Brazil (CAPES).

MATEUS MATOS DA SILVA Graduating in Bachelor of Biotechnology from the Federal University of Alfenas.

RAFAELA SIMEI POPOLIM Graduate in Foreign Trade, Graduated in Translator and Interpreter. Teacher in professional training courses in English classes.

CRISTIAN RIBEIRO GONÇALVES Master student in Health Promotion from the University of Franca. Graduated in Physical Education (bachelor and bachelor degree) from the University of Franca. Postgraduate in Tutoring in Distance Education from São Luís College of Education.

MATHEUS REIS SANTOS DE MELO Graduating in Biological Sciences from the University of Franca. Scientific Initiation in the Laboratory of Mutagenesis.

DANILO CÂNDIDO BULGO Master's degree in the Postgraduate Program in Health Promotion of the University of Franca. He has a degree in Physiotherapist, Translator and Interpreter and Pedagogy at the University of Franca and specialization in Psychopedagogy, Collective Health and Health Services Management. She is a face-to-face tutor from the University of Franca. 